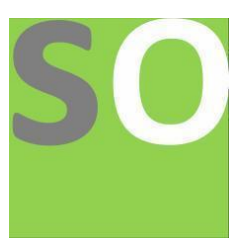

Article title: Communicative Approach in the Five Curricula of English Subject for Secondary Schools: A Paradox in English Language Teaching in Indonesia

Authors: HARITS MASDUQI[1], NOVI PRIHANANTO[2]

Affiliations: Department of English, Faculty of Letters, Universitas Negeri Malang, Indonesia[1], The English Department, Faculty of Cultural and Social Sciences, Gajayana University of Malang[2]

Orcid ids: 0000-0002-7661-7088[1], 0000-0003-0367-5786[2]

Contact e-mail: harits.masduqi.fs@um.ac.id

License information: This work has been published open access under Creative Commons Attribution License http://creativecommons.org/licenses/by/4.0/, which permits unrestricted use, distribution, and reproduction in any medium, provided the original work is properly cited. Conditions, terms of use and publishing policy can be found at https://www.scienceopen.com/.

Preprint statement: This article is a preprint and has not been peer-reviewed, under consideration and submitted to ScienceOpen Preprints for open peer review.

Funder: Department of English, Faculty of Letters, Universitas Negeri Malang, Indonesia

DOI: 10.14293/S2199-1006.1.SOR-.PPHBZCF.v1

Preprint first posted online: 11 February 2021

Keywords: communicative approach, communicative language teaching, CLT 


\title{
COMMUNICATIVE APPROACH IN THE FIVE CURRICULA OF ENGLISH SUBJECT FOR SECONDARY SCHOOLS: A PARADOX IN ENGLISH LANGUAGE TEACHING IN INDONESIA
}

\author{
Harits Masduqi \\ harits.masduqi.fs@um.ac.id \\ Universitas Negeri Malang
}

\author{
Novi Prihananto \\ noviprihananto@unigamalang.ac.id \\ Universitas Gajayana Malang
}

\begin{abstract}
The English curriculum implemented in the Indonesian secondary schools has undergone some development in the past few decades. The development is meant to ensure that the curriculum remains up to date with the development of English language teaching theories and practices in the world. This paper discusses the English curricula which were developed in 1984, 1994, 2004, and 2006 and critically analyses the communicative approach that has been implemented in Indonesian secondary schools. The newest 2013 curriculum is also discussed, but only superficially as the curriculum was just officially implemented at national level in the end of 2019. The writers finally offer some recommendations for future curriculum developers and government officials in order to improve English language teaching and learning in Indonesia.
\end{abstract}

\section{Keywords}

communicative approach, communicative language teaching, CLT

For more than seven decades, the Indonesian government has been working determinedly to manifest a standard form of English language teaching that can assist students to meet the demands of economy, science, and technology developments. Following current trends of English language teaching in the world, the curriculum designers have decided to use communicative approach across the educational levels since 1984. This is a 'dramatic' change that tries to tackle problems with approaches and theories adopted before it (Huda, 1999; Lie, 2007; Madya, 2007, 2008; Marcellino, 2008; Renandya \& Widodo, 2016; Sukyadi, 2015).

Despite the change in the curriculum, however, the concern of most English teachers remains unchanged. English teaching still deals mainly with the complex 
structures of the language, non-contextual vocabulary items, and other activities that are far from the real purpose of communicative approach (Lie, 2007; Madya, 2008; Marcellino, 2008; Mattarima \& Hamdan, 2011). The facts show the contradiction between the principles of the communicative approach and the actual implementation in classrooms. No wonder Indonesian students still find it difficult to speak English communicatively (Lie, 2007; Madya, 2007; Renandya \& Widodo, 2016).

The Indonesian government has tried hard to develop and implement a new curriculum almost in every leadership term of Ministry and Education and Culture. There are five English curricula which have applied communicative approach in Indonesia: the 1984 Curriculum, the 1994 curriculum, the 2004 Competency-Based Curriculum, the 2006 School-Based Curriculum or Kurikulum Tingkat Satuan Pendidikan/KTSP, and the 2013 Curriculum. Each new curriculum was expected to be more effective in guiding and improving the English language teaching and learning in Indonesia. Nevertheless, each curriculum has caused problems in its implementation as English teachers find it hard to meet the demands of the curriculum while at the same time, they have to prepare their students for the national examination.

This paper discusses each curriculum and critically analyses its communicative approach that has been implemented in Indonesian secondary schools. To begin with, the writers first review the five curricula based on the historical perspectives of English language teaching and curriculum development in Indonesia. The writers, then, critically discuss issues with the communicative approach in the theoretical and practical concepts. The writers finally offer some recommendations for curriculum developers and government officials in order to improve English language teaching and learning in Indonesia. 


\section{BRIEF REVIEW OF THE COMMUNICATIVE APPROACH IN THE ENGLISH CURRICULA OF INDONESIAN SECONDARY SCHOOLS}

\section{The 1984 English Curriculum}

The 1984 English curriculum for secondary schools adopted an initial version of the communicative approach with an emphasis on the development of reading skills (Huda, 1999). This was due to the lack of a linguistic environment that could enable real oral-aural communication in English. Because English is not used in Indonesia either socially or for official communication, as it is in Hong Kong, Singapore, and the Philippines, but is viewed as just a foreign language, it is only taught in schools as a subject for study, not as a tool for communication. The limitations of the linguistic environment in Indonesia deprive students of the opportunity of learning and using more spoken English for oral communication (Huda, 1999), even though the government, through the 1984 English curriculum, expected that the objective of the teaching was to restore the true goal of English teaching, that is, "meaningfulness and communicative functions" (Ministry of Education and Culture, 1986 and 1987, as cited in Huda, 1999). The 1984 curriculum seemed to be a reaction or correction to the errors and problems found in the implementation of the previous curriculum (the 1975 curriculum), especially in the development of the teaching materials as reported by the British Council (1975). Unfortunately, the syllabus and textbooks in that era still used the structural approach, where the main focus was on learners' competence in the grammatical structure of the English language (Huda, 1999). Therefore, mismatches occurred between government expectations and what happened in the classroom, as found by Huda (1999) in his survey of 26 provinces in Indonesia.

With regard to the format of the curriculum document, the 1984 curriculum is written in a column format, in which the columns refer to curricular objectives, instructional objectives, instructional materials, lesson programs and techniques of teaching, resource materials, and assessment (Huda, 1999). Each curricular objective is developed into several instructional objectives, and each instructional objective is then developed into topics and sub-topics. Although this format makes clear relationships 
between objectives, materials, and techniques, the syllabus is very rigid (Huda, 1999; Yulia, 2014). Teachers and textbook writers do not seem to be allowed any creativity in writing or using syllabuses and textbooks (Huda, 1999).

\section{The 1994 English Curriculum}

Huda (1999) makes a pertinent observation about the changes from the 1984 curriculum to the 1994 curriculum:

The claim that the 1984 syllabus adopted a communicative competence approach has created a number of misunderstandings and misinterpretations. One of the serious misinterpretations is that English instruction in secondary schools is targeted toward the acquisition of oral communicative competence. The term "communicative competence" seems to be a source of misinterpretation. Therefore, in the statement of objectives in the 1994 syllabus, the phrase "communicative competence" is avoided, although the objective is still the development of competence to communicate in English. Similarly, the term "communicative competence approach" will also be avoided, in spite of the fact that the syllabus has the elements of notional, functional, and situational syllabi. Instead, a new term has been invented to describe the teaching approach and method which is suitable to achieve the objective. The approach to teaching is labelled the "meaningful approach". (p. 124)

The 1994 English curriculum was developed by a team that consisted of English teaching specialists, curriculum specialists, practicing teachers and school system authorities, and was also based on the 1987-1990 national surveys on the teaching of English in the secondary schools in 26 provinces in Indonesia (Huda, 1999). The development of the curriculum was conducted in three stages: (1) research, evaluation, and writing stage, (2) preparation stage, and (3) implementation stage (Huda, 1999). The goal of the curriculum was broadened to include listening, speaking and writing skills, but the main focus was still to develop reading skills in English, with a vocabulary level of 1000 words for junior high school and 2500 words for senior high school. It was suggested at this time that the English curriculum should be suitable for varying sociogeographical needs, so three versions of the English syllabus were planned: (1) national content, which would be implemented nationally, (2) enrichment content, which would be implemented with students who have achieved the level of the national content, and (3) local content, which would satisfy regional or local needs (Huda, 1999). 
As a significant shift in curriculum renewal, the Local Content Curriculum (LCC) was introduced and implemented in the 1994 curriculum (Yue, et al., 2006). In consequence, the curriculum devoted $20 \%$ of the time to locally designed subjects (Yulia, 2014), which meant a shift from the centralized curriculum (pre-1994) that had been implemented in the previous era to a focus on locally needed subjects, such as topics on agriculture, information technology, or home industries. Unfortunately, Bjork (2006, p. 140) found in his research that the shifts were only superficial, as "instructors continued to use the curricular materials and instructional methods they had relied on for years; only the titles of those classes or the manner in which they were configured (such as the sequence of topics presented) had been altered".

A new flexible syllabus development format was introduced in this curriculum to avoid the problems that had occurred in the previous curriculum. Textbook writers and teachers could change the sequence of the syllabus items, which was in a default order set by the curriculum developer (Huda, 1999). However, problems and questions still arose as to which format provided the best guide without sacrificing the creativity of either the teachers or the textbook writers.

The idea of a competence-based curriculum and the insertion of local content from the 1994 curriculum continued to be improved over the following years. This was part of the government's efforts to decentralize the authority and acknowledge local values to improve the quality of education (Pusat Kurikulum Departemen Pendidikan Nasional, 2003; State Secretariat of the Republic of Indonesia, 2003). The improved competence-based curriculum was trialed in certain areas of Indonesia from 2000 to 2004, when the 2004 curriculum was officially introduced.

\section{The 2004 English Curriculum}

The 2004 curriculum could be considered part of the results of government policies on decentralization following the political reform after the fall of the New Order Regime (the fall of Suharto) in 1998. The major educational reform was the shift from a centralized to a decentralized system. Based on Law number 20 on the National Education System, year 2003 (State Secretariat of the Republic of Indonesia, 2003), in 
which the policy of decentralization in education was released, the Ministry of National Education (MONE) developed regulations for a school-based management curriculum (Pusat Kurikulum Departemen Pendidikan Nasional, 2003) and a competence-based curriculum (Pusat Kurikulum Balitbang Depdiknas, 2003). At this time, MONE seemed to focus on the development of the competence-based curriculum first, even though the policy of the school-based management curriculum was already released and was being trialed. Therefore, the 2004 curriculum was named Kurikulum Berbasis Kompetensi (KBK or Competence-Based Curriculum).

The development of this curriculum was influenced by the development of a paradigm of philosophy, learning, and language theory (State Secretariat of the Republic of Indonesia, 2003). This curriculum employed a competence-based approach, and the aim of the English subject in the national education system was thus to develop learners' competence in English (State Secretariat of the Republic of Indonesia, 2003). Although this 2004 curriculum employed the same competence-based label as the 1984 and 1994 curricula, the difference, as noted in Huda (1999), was in the explicitness of the term "communicative competence approach" used. In the previous curricula that term was not used, in order to avoid serious misinterpretations and misunderstandings. However, in the 2004 curriculum, the English curriculum developers incorporated the Communicative Competence model proposed by Celce-Murcia et al. (1995), which consisted of five subcompetences: linguistic competence, sociocultural competence, actional competence, strategic competence, and discourse competence (Agustien, 2004).

As the main goal of this model of Communicative Competence focuses on discourse competence, the curriculum developers also incorporated the Systemic Functional Linguistic (SFL) Genre-Based Approach (GBA) proposed by Halliday (Emilia, 2005; Halliday, 1994). Agustien (2004) argues that since the government employed a competence-based curriculum and the relevant approach to teaching English in Indonesia by using Communicative Competence (CC) concepts, then the generic structures of both conversational and written texts should be introduced into the curriculum. These generic structures of conversational and written texts are features of 
the GBA and are in line with the discourse competence of CC (Agustien, 2004, 2006). Agustien (2004) argues:

In short, at junior high level, learners are expected to learn daily expressions, especially fixed expressions and idioms that are needed in daily lives to accompany their actions when playing at the school yards, when attending the class, when interacting with their friends, etc. They should be encouraged to read English for fun and to collect English that they like from different sources, such as fairy tales, jokes etc. At the senior high level, they develop those skills further and they move to more distant communications involving subtleties or nuances of meaning: interpersonal, ideational, and textual meanings." (p. 3)

\section{The 2006 English Curriculum}

Two years after MONE released the 2004 curriculum, the 2006 School-Based Curriculum was officially released. This curriculum was well-known as KTSP (Kurikulum Tingkat Satuan Pendidikan or the School-Based Curriculum). The implementation of this curriculum was started in 2006 when the government released Law number 20 on the National Education System to provide provinces and districts with the autonomy to manage their own systems of education. The 2006 curriculum included eight education standards along with the competence-based standards (Board of National Standards of Education, 2006).

The 2006 English curriculum was similar to its predecessors, it added (1) the inclusion of a school-based management curriculum where teachers were given more autonomy to elaborate the national (core) curriculum according to their local contexts (Board of National Standards of Education, 2006), and (2) text types (genres) in the curriculum were divided into two groups and simplified (Agustien, 2006). The main differences between the 2004 English curriculum and the 2006 curriculum were in the main document that described the core standards and their indicators and also in the model syllabus. In addition, many components that had been present in the 2004 English curriculum main document were omitted in the 2006 English curriculum. The competence indicators, essential learning materials, and appendices were withdrawn, leaving only the standards and basic competences stipulated by the Board of National Standards of Education (BNSE or Badan Standar Nasional Pendidikan/BSNP) (Sukyadi, 
2015). The competence indicators were withdrawn to give autonomy to the teachers and schools to develop the curriculum to suit their local contexts, and to avoid the controversies that occurred with the 2004 curriculum when the new GBA approach was introduced. BNSE expected teachers and schools to have more opportunity to develop their own curriculum to be able to cater for local needs when implementing the Kurikulum Tingkat Satuan Pendidikan (School-Based Curriculum) (Sukyadi, 2015; Widodo, 2016). Some sub-competences were mentioned in the 2004 curriculum documents as indicators to be attained, while the 2006 curriculum documents focused more on the language skills indicators (listening, reading, speaking, and writing) to be attained, rather than mentioning the sub-competences of Communicative Competence (CC); likewise, the model syllabuses of the 2006 curriculum rarely mention the subcompetences of $\mathrm{CC}$.

\section{The 2013 Curriculum}

In 2013, the Ministry of National Education (MONE) introduced yet another new curriculum, but they had been motivated by the increasing concerns among Indonesians about a rising flood of immorality and intolerance among Indonesian youths (Kennedy, 2014). This new curriculum adopted aspects of character education in almost all of the subjects. In addition to character education, the 2013 curriculum aimed to improve Indonesian education by reducing and changing the required subjects. At the primary level, the Ministry cut the required subjects from ten to six; and English, science, and IT classes were eliminated in favour of more time for classes viewed as character-boosting, such as Bahasa Indonesia, civics, and religious studies. At the secondary level, teaching hours in English and IT classes were reduced in favour of history and local language classes (Kennedy, 2014).

With regard to English language teaching and learning for secondary education, Widodo (2016) states that the 2013 curriculum does not detail key elements, such as curriculum materials, pedagogy, and assessment, based on relevant theories of language, language learning, and language teaching. Instead, engaging learning and teaching are framed in a form of scientific inquiry (the 'Scientific Approach') or discovery learning, 
which follows five steps: observing, questioning, exploring or experimenting, associating, and communicating. Further, Widodo (2016) states:

The nature of the current curriculum is highly prescriptive in that it dictates what and how to teach and learn English within the remit of predetermined competences. Both core and basic competences are set based on the ideological and political agenda. These competences do not reflect communicative language competence and the totality of competences that students have to develop to become competent users of English. (pp. 138139)

It seems that this new curriculum has not only brought in totally new concepts beyond the known and established language teaching approaches, but also returned to the era when teachers were spoon-fed with the prescribed curriculum, as in the pre-2006 curricula. There have been a lot of problems and difficulties from the initial stages of the curriculum implementation up to the present. Among other things, the problems lie in the fact that the curriculum documents were not ready on time to be disseminated, which consequently created confusion and misunderstanding among teachers and their schools (Rachman, 2014). Up to the end of 2014, there were still some schools that had not received the curriculum documents: $19 \%$ of the elementary schools, $32 \%$ of the junior high schools, and 22\% of the senior high schools around Indonesia (Rachman, 2014). Another problem is that the content of the curriculum documents does not seem to be comprehensive and complete, which creates more burden for the teachers in implementing it (Rachman, 2014). These problems continue even now.

Fortunately, in response to the complaints from the schools, on December 11, 2014, the Minister of Education and Culture issued a ministerial regulation (Ministry of Education and Culture of the Republic of Indonesia, 2014) that both the 2006 curriculum and the new 2013 curriculum could be used, depending on whether or not the particular school was ready and prepared to implement the new 2013 curriculum. If the school was not ready, then it could still continue to use the 2006 curriculum. The deadline to replace the 2006 curriculum with the new one is in the end of 2019; after that year all schools in Indonesia must implement the 2013 curriculum.

Theoretical issues, as it is explained in the section below, concern the most appropriate approach of ELT for secondary education in Indonesia. Clearly, 
Communicative Competence and the Genre-Based Approach that were adopted (as explained above) have not achieved as planned. There are two main reasons for this failure. First, even though the five sub-competences in the new model adopted were combined into one discourse competence as stated in the 2004 Curriculum, they still appeared to be a burden for the teachers to implement, and the embedded Genre-Based Approach (as stated in the 2004 and 2006 Curricula) was even more difficult. These two new concepts should be thoroughly learned and practised by the teachers before they implement them in their classrooms. The curriculum developers should also seek other approaches that would suit the education contexts in Indonesia.

\section{ISSUES WITH THE IMPLEMENTATION OF COMMUNICATIVE}

\section{LANGUAGE TEACHING}

\section{Paradox in the Theoretical Concepts}

Some of the benefits of Communicative Language Teaching (CLT) have been criticised by some as rather questionable and inconsistent, and they could be regarded as the weaknesses of the approach rather than its strengths (Didenko \& Pichugova, 2016). The proponents of the various theories and concepts underlying CLT have never come to agree on some fundamental issues, such as actually defining Communicative Competence. Three different models of Communicative Competence were produced by Canale and Swain (1980), Celce-Murcia et al. (1995), and Bachman and Palmer (1996) during more than ten years of studies, but whether such models have made CLT more manageable in classroom application seems doubtful (Brown, Tarone, Swan, \& Ellis, Rod, 2007; Butler, 2011; Swan, 1985; Vongxay, 2013). Didenko and Pichugova (2016) argue that one reason why CLT failed to achieve its ideal goal is that it attempted to embrace so many language-related disciplines at once. This is based on Thomson's (1996) and Widdowson's (2009) argument that those who adopted the models and

principles of CLT from mainly the linguistic theories simply omitted unattractive or ambiguous parts, producing a fragmented and confusing mixture of misconceptions about models and conflicting ideas, like teaching no grammar at all, or teaching only speaking. 
There is considerable criticism of CLT, which is based on evidence that CLT has failed to fulfil its many promises to innovate language teaching. One foremost issue is the lack of real communicativeness in the approach (Didenko \& Pichugova, 2016; Kumaravadivelu, 2006; Nunan, 1987, 2003). Nunan (1987) argues that CLT teachers cannot manage to create real-life communication in their classes as well as to create conditions conducive for developing communication skills. Seedhouse (1996) states that the goal of CLT to replicate genuine or natural communication rather than typical or traditional communication styles in classroom communications is both paradoxical and unattainable. He argues that it would be more satisfactory to take an institutional discourse approach, where classroom discourse is regarded as an institutional variety of discourse, in which interactional elements correspond appropriately to institutional goals (1996, p. 16). Kumaravadivelu (2006) adds that CLT cannot promote authentic communication, because, based on his study, CLT has failed to describe classroom interaction as genuinely communicative.

Another reason why CLT failed to fulfil its promises is its inability to fit into certain contexts (Didenko \& Pichugova, 2016); likewise, studies from various countries reported by Kumaravadivelu (2006) showed general dissatisfaction has arisen as a result of the lack of compatibility of CLT with local contexts. CLT implementation has turned out to be actually distressing at times for teachers and students alike, especially in EFL contexts where both the teachers and the students were non-native speakers of English, even in cases when it was backed by governments and institutional authorities (Butler, 2011; M. Chang, 2011; Didenko \& Pichugova, 2016; Drame, 2009; Huda, 1999; Lie, 2007; Madya, 2008; Marcellino, 2008; Mattarima \& Hamdan, 2011; Musa, Lie, \& Azman, 2012; Vongxay, 2013; Yulia, 2014). Most researchers believe that differences in culture between differing teaching and learning communities present a very difficult hurdle for CLT practices as national language policies (B. Chang, 2011; M. Chang, 2011; Lie, 2007; Madya, 2008, 2007)

Richards and Rodgers (2014, pp. 103-105) summarise criticisms of CLT as follows: 
- It promotes fossilisation. The promise that the communicative classroom activities would help learners develop both communicative and linguistic competence did not always happen. In the early stages of learning, it was reported that students often developed fluency at the expense of accuracy, resulting in students with good communication skills but a poor command of grammar and a high level of fossilisation (Higgs \& Clifford, 1982).

- It reflects "native-speakerism". The teaching methods developed in the countries of English origin reflect the kinds of learners who study in institutes and universities serving students who generally have instrumental reasons for learning English, namely for academic or professional purposes or as new settlers, and the teaching methods also reflect its cultures of English origin as well. Such learners' needs may be very different from learners learning English in state-based educational programs in other parts of the world. Holliday (1994) points out that most literature on CLT reflects primarily the understandings of countries of English origin about teaching, learning, teachers, and classrooms. In these contexts, English language teaching tends to be instrumentally oriented; while in non-English-speaking countries, English is taught as part of a wider curriculum and is influenced and constrained by wider educational, institutional, and community forces, quite different from those in the English-speaking countries.

- It is not applicable in different cultures of learning. Attempts to implement CLT in non-European settings have often been less than successful due to different assumptions about the nature of teaching and learning that learners in countries such as China, East Asia, and other contexts bring to learning (Ahmad \& Rao, 2012).

- It reflects a Western-based top-down approach to innovation. Kumaravadivelu (2012) argues that the communicative syllabus and common procedures for its implementation do not capture the diversity of students' needs and goals.

To conclude, CLT appeared at a time when language teaching in many parts of the world wanted a paradigm shift, since language teaching methods such as situational language teaching and audiolingualism were no longer felt to be appropriate methodologies. CLT emerged to those who sought a more naturalistic and humanistic approach to language teaching, where the interactive processes of communication were 
the priority goal (Richards \& Rodgers, 2014). However, this approach did not always go smoothly without criticisms as has been mentioned above.

\section{Paradox in the Practical Concepts}

Despite the continuous changes in the curriculum, the concern of most English teachers remains unchanged. English teaching still deals mainly with the complex structures of the language, long reading passages, too technical vocabulary items, and other activities that are far from the real purpose of the current curriculum. The facts show the contradiction between the principles of the communicative approach and the actual implementation in classrooms (Lie, 2007; Madya, 2007; Marcellino, 2008; Mattarima \& Hamdan, 2011; Sukyadi, 2015; Widodo, 2016).

As gaining communicative competence requires certain enabling conditions in order that it can be applied effectively_-such as, the existence or good language models from whom students can learn language, a great deal of exposure to the language in the real-life situations, the involvement in meaningful communication-we have seen from the beginning of the curriculum implementation to date that such conditions are

potentially contradictive with the language learning environment in Indonesia. The theoretical understanding on a supportive language environment might not be well translated into practice in educational fields, particularly in the classrooms (Bjork, 2005, 2013; Huda, 1999; Madya, 2007; Marcellino, 2008; Mattarima \& Hamdan, 2011).

One of the main features of communicative language teaching is its focus on learners. Richards and Rodgers (2014) state that in a communicative language teachingbased classroom, language teaching should be learner-centred and responsive to their needs and interests. Indonesians, in general, including most teachers and students, are not accustomed to the idea that learning activities are more student-generated than teacherinitiated. The widely held belief is that teaching is passing down knowledge from teachers to students, that teacher knows everything, and that student is knowledge recipient from teacher. Because of such beliefs, it is very unrealistic to hope that the students will be very active in their learning situations. In fact, Indonesian classrooms are renowned as unidirectional and quiet ones (Bjork, 2013; Djalal et al., 2009; Huda, 1999; Sadtono, 1997; Widodo, 2016). 
In addition to the absence of the enabling conditions (such as communicative activities in the classrooms), these students have had a pre-structured attitude that the measure of being good or not good students is judged from their obedience to the guru (teacher), who must be digugu (trusted with everything they say) and ditiru (imitated). Being a good student also means taking for granted whatever the teacher gives without questioning mind. Shifting the role of the teachers as learning conductors to teaching facilitators is also much easier to be said than to be done. Teachers are considered school time parents for Indonesian students, and being "parents" means that they should always play a leading role in the classroom (Bjork, 2005, 2013; Djalal et al., 2009).

The number of teaching materials that support the implementation of communicative competence at schools is limited. This is in contrast to private language courses that generally have stronger financial resource than formal schools. Being financially established, they can provide decent facilities to support English language learning. Moreover, Indonesian senior high school teachers' quality in research is relatively low (Bjork, 2005, 2013). The teachers do not have enough opportunities to research their teachings or even to keep up to date with the research in English teaching areas (Bjork, 2013; Djalal et al., 2009). Consequently, their classroom management skills are low and, most importantly, they may find it hard to translate the idea of communicative competence model into the actions. This leads to a situation in which no significant change takes place on the way they teach and nurture the students' learning. Limited teaching skills, coupled with large classrooms of varying abilities, have driven these secondary school teachers to a dilemmatic position (Bjork, 2005, 2013; Huda, 1999; Marcellino, 2008; Mattarima \& Hamdan, 2011; Widodo, 2016).

\section{CURRENT DEVELOPMENT OF CLT TOWARDS THE $21^{\mathrm{ST}}$ CENTURY}

The early communicative approach considered target language-based communicative competence to be essential in order for foreign language learners to participate fully in the target language culture (native-speakerism). It was this monolithic perception of language and culture that has made the early paradigm utopian in character and, therefore, failed to reflect the lingua franca status of English language (Braine, 2010; 
Byram, 2008). This early paradigm of CLT is difficult to implement when English is increasingly used throughout the world by speakers of many different first languages. English has become the international language of communication in the twenty-first century, and within a short period of time the number of people who speak English as a non-native language may exceed the number of its native speakers (Braine, 2010; Renandya \& Widodo, 2016).

It is becoming apparent that real communicative activities ought to be redefined in relation to the reality of English as an International Language (EIL) (Byram, 2008; Renandya \& Widodo, 2016). This involves not only the uses of English that are real for its native speakers in English-speaking countries, but also the uses of English that are real for its non-native speakers in communities served by languages other than English (Alptekin, 2002; Braine, 2010). Therefore, the conventional early model of CLT, with its strict adherence to native speaker norms within the target language culture, would appear to be invalid in cross-cultural settings (Byram, 1997; Renandya \& Widodo, 2016). Nowadays CLT should view English as a means of international and intercultural communication involving the following criteria:

- Intercultural communicative competence should be developed among EIL learners by equipping them with linguistic and cultural behaviour which will enable them to communicate effectively with others, and also by equipping them with an awareness of differences, and with strategies for coping with such differences (Byram, 2012; Coperías-Aguilar, 2002; Hyde, 1998).

- Instructional materials and activities should have suitable discourse samples involving native and non-native speaker interactions, as well as interactions between non-native speakers (Coste, Moore, \& Zarate, 2009; Widdowson, 2007).

- Instructional materials and activities should involve local and international contexts that are familiar and relevant to language learners' lives (Alptekin, 2002; Byram, 2008; Coperías-Aguilar, 2002; Coste et al., 2009). 
- Appropriate integration of technology in the classroom encourages students to use language in different ways and brings real-world issues into the classroom (Richards, 2006). Learners from different parts of the world can get connected and exchange ideas. Many students may know more than their teachers about how to use technology, and yet they need proper guidance from their teachers on how to select, analyse, and utilise the right information to achieve their learning goals. The classroom activities currently applied in CLT can also provide new roles for students and teachers in classrooms; now, students take part in cooperative classroom activities where they learn from their peers by doing pair or group tasks (Richards, 2006).

The above examples bring the chance of plurilingualism and plurilingual education to $21^{\text {st }}$-century language learners who already have some intercultural communicative competence (Byram, 2008, 2012). Plurilingual competence is the capacity to successively acquire and use different competences in different languages, at different levels of proficiency and for different functions. The central purpose of plurilingual education is to develop this competence (Beacco \& Byram, 2007). The concept of plurilingual competence refers to the Council of Europe's standard distinction between plurilingualism and multilingualism (Council of Europe, 2001): plurilingualism is the ability to use more than one language - and accordingly involves seeing languages from the standpoint of speakers and learners (Beacco, Byram, Cavalli, Coste, \& Cuenat, 2010). Multilingualism, on the other hand, refers to the presence of several languages in a given geographical area, regardless of who speaks them; speakers in this geographical area may not be equally proficient in each of the different varieties represented (Beacco \& Byram, 2007). Beacco et al. (2010) argue that this approach would be incomplete without the pluricultural and intercultural dimension:

Pluriculturality is the desire and ability to identify with several cultures, and participate in them. Interculturality is the ability to experience another culture and analyse that experience. The intercultural competence acquired from doing this helps individuals to understand cultural difference better, establish cognitive and affective links between past and future experiences of that difference, mediate between members of two (or more) social 
groups and their cultures, and question the assumptions of their own cultural group and milieu. (Beacco et al, 2010, pp. 16)

Therefore, nowadays Communicative Competence (CC) would more appropriately be termed Intercultural Communicative Competence as has already been argued by Michael Byram since 1997 (Byram, 1997).

\section{APPROACHES TO ENGLISH LANGUAGE TEACHING AND LEARNING IN THE $21^{\text {ST }}$ CENTURY}

There are some core and essential skills required in education in the $21^{\text {st }}$ century. These comprise skills, abilities, and learning dispositions that have been identified as being required for success in $21^{\text {st }}$ century society and workplaces by educators, business leaders, academics, and governmental agencies. This is part of a growing international movement focusing on the skills required for students to master in preparation for success in a rapidly changing, digital society. Many of these skills are also associated with deeper learning, which is based on mastering skills such as analytic reasoning, complex problem solving, and teamwork. These skills differ from traditional academic skills in that they are not primarily content-knowledge-based (Bellanca, 2014).

In 2002 a national organisation in the United States made up of non-profit foundations and private companies, called The Partnership for $21^{\text {st }}$ Century Skills, proposed the need for these $21^{\text {st }}$ century skills for every student (Bellanca, 2014; Dede, 2009). This organisation, popularly called P21, defines $21^{\text {st }}$ century skills as a blend of content knowledge, specific skills, expertise, and literacies necessary to succeed in work and life (Ledward \& Hirata, 2011). These skills are more than mere technological literacy; in addition, they include proficiency in critical thinking, problem solving, communication, and team work (Paige, 2009). Based on the three main areas of skills mentioned above, there are seven key skills, named 7Cs skills, proposed by the senior members of the organisation (Trilling \& Fadel, 2009): (1) critical thinking and problem solving; (2) creativity and innovation; (3) collaboration, teamwork, and leadership; (4) cross-cultural understanding; (5) communication and media literacy; (6) computing and ICT literacy; and (7) career and learning self-reliance. 
Regarding the integration of these $21^{\text {st }}$ century skills into English language teaching and learning, Yilin Sun (2016, pp. 1-6) proposed nine strategies to empower ELT professionals:

Strategy 1 - Value the changing perspectives on ELT: English language teaching and learning have undergone many changes over the past 50 years, which have become increasingly apparent in the past 20 years. Code-switching once was seen as language error, but now has been recognised as a valuable bilingual and translanguaging resource. An accent, instead of being viewed as deficiency, now reflects identity. The purpose of English language learning has moved away from copying native speakers as closely as possible to successful use of skills and strategies to be effective and competent communicators for a world-wide work force.

Strategy 2 -Embrace changes in goals of English teaching and learning: with the changing perspectives on ELT, the goals of ELT have also changed from focusing solely on developing language skills and mimicking native English speakers to also fostering a sense of social responsibility in students.

Strategy 3 - Integrate $21^{\text {st }}$ century teaching-learning approaches: the 7Cs skills (mentioned above) proposed by Trilling and Fadel (2009) have been implemented by more schools particularly in the USA in recent years. In addition, eclecticism in ELT is becoming more popular nowadays (Brown, 2007; Kumaravadivelu, 2001, 2012). Eclecticism involves the use of a wide variety of language learning activities, each of which may have very different characteristics and may be motivated by different underlying assumptions.

Strategy 4 - Understand changes in research approaches: ELT research studies nowadays have moved from a single focus on the designs and methods of quantitative empirical research to the inclusion of qualitative and other alternative approaches, with designs that incorporate both quantitative and qualitative elements.

Strategy 5 - Expand the dimension of Communicative Competence: so many recent research publications have shown the expanding framework of communicative competence. Pioneered by Vivian Cook (1992, 2012, 2016), some scholars (Choong, 
2006; Doyle, 2015; Hall, Cheng, \& Carlson, 2006; MacKenzie, 2012; Scott, 2015) have introduced an expanded view of communicative competence as "multi-competence" in second language acquisition and learning. Other scholars, including Michael Byram (1997), have focused on the importance of intercultural communicative competence in English as a foreign language teaching and learning (Byram, 2008, 2012; Corbett, 2003; López-Rocha, 2016; Sercu et al., 2005). The implication here is that when teaching intercultural communicative competence, teachers need to teach both local and international cultures. The goal is to produce effective language users to use English as a global Lingua Franca, not just learners who mimic the "inner-circle" countries' language and culture.

Strategy 6 - Teach and learn in a $21^{\text {st }}$-century context: in a globalised world, it is not uncommon to form a team of, say, four people from different continents in a collaborative project. Hence, educators need to be aware of the changes to better prepare students with $21^{\text {st }}$-century skills to compete in the competitive workforce; so both language teachers and learners should understand and use all the 7Cs skills.

Strategy 7 - Apply macro strategies to enhance assessment: Standards-based assessment programs which measure success based on student learning (achievement of standards), rather than on compliance rules, have been implemented by many schools nowadays. However, as Darling-Hammond et al. (2003) have advocated, the reform of assessment of student learning needs "top-down support for bottom-up reform." This strategy seeks to empower teachers and principals at the "bottom" of the system to solve problems more effectively by organising intensive professional development and creating a culture of shared norms of practice from the "top" and "bottom" simultaneously. This strategy wrestles with outside influences to use them to the advantage of "inside" purposes without being carried off course by the force of their momentum. Once this happens, educators will be empowered to apply macro strategies to enhance assessment. Macro strategies refer to overall plans obtained from L2 related pedagogical, experiential and theoretical knowledge (Kumaravadivelu, 2003). The assessment tools should be designed to engage students in active learning and demonstrate their skills in real-world performance-based projects. 
Strategy 8 - Be ready for rapid development and integration of information technology in ELT: Rapid developments in technology and the use of cell phones and multimedia devices have opened endless possibilities for English teachers to access information, while the Internet, YouTube, Web.2.0, and e-books have helped teachers prepare more varied lessons and classroom activities connected with the modern world. With ready-made materials available at the stroke of a key it is possible to bring real life into the classroom.

Strategy 9 - Embrace changing roles and increasing responsibilities of teachers: Teachers have multiple roles and responsibilities as facilitators of student learning and creators of a productive classroom environment in which students can develop the skills they will need for the $21^{\text {st }}$ century workforce. Nowadays, many teachers benefit when they integrate content and project-based approaches, and changes in classrooms such as shared teaching, team teaching, and collaboration with other teachers. In this innovative approach, excellent resources and opportunities are provided for educators. Teachers need to embrace new ideas to effectively teach in our ever-changing societies. This also prepares teachers to be reflective practitioners and constructive social agents in the world of globalising the English language (Sun, 2014).

The focus of language education in the $21^{\text {st }}$ century is no longer simply on grammar, memorisation and learning by rote, but rather using language and cultural knowledge as a means to communicate and connect to others around the globe (Eaton, 2010; Kumaravadivelu, 2012; Savignon, 2007). Technology has transcended geographical and physical boundaries when students learn to use language and cultural skills to reach the world around them (Eaton, 2010). Learning is typically focussed on the types of competencies which include digital literacy, cultural competence, inventiveness, emotional awareness, entrepreneurship, critical thinking, and problem solving (Abentao, Castillo, Atitiw, \& Asuncion, 2018). Abentao et al. (2018) argue that many innovative ideas and policies need to be developed to meet the needs of culturally diverse classrooms because people from different locations, especially non-English speakers, are learning the English language in order to compete in the career world, and, therefore, suggest educational institutions should make every classroom multicultural, more learnercentred, more collaborative and more technologically driven. 


\section{CONCLUSIONS AND RECOMMENDATIONS}

Curriculum developers should consider both technical issues (practical problems) and theoretical issues when developing a curriculum innovation. Technical issues may be resolved by monitoring and supervising whether every school meets the national standards in education equally. These issues are very difficult to resolve, as there is a wide disparity in socioeconomic backgrounds in every province in Indonesia, especially between the provinces on Java island and outside Java island. The national examination is, consequently, not set on an equal footing for every region (Lie, 2007).

Another technical issue concerns the format and development of the curriculum documents themselves. Government authorities such as CCD and BNSE should professionally and continuously review and monitor the process of publishing and disseminating the curriculum documents and their companion documents to the hands of the forefront implementers, the classroom teachers. These authorities should not confuse the teachers when a new curriculum as a new education innovation is ready to be implemented; otherwise, this innovation will not achieve what it is intended to achieve. Widodo (2016), for example, questioned the theoretical foundation of the new 2013 curriculum when he found that this curriculum was more driven by ideological and political agendas than pedagogical reasons. Teachers are fed with this new curriculum that has been determined as in the pre-2006 curriculum era but with a completely new concept outside the language teaching approach that is well known and established. There have been many problems and difficulties during the implementation of this new 2013 curriculum to date. Among other things, the problem lies in the fact that curriculum documents are not ready on time for dissemination, which consequently creates confusion and misunderstanding among teachers and their schools (Rachman, 2014). Indeed, new 2013 curriculum amendments are still happening. Therefore, any future curriculum should be 'friendlier' for the implementers and the users.

Recommendations and key ideas suggested by EFL researchers and English

teacher organisations, such as TEFLIN (The Association of Teaching English as a Foreign Language in Indonesia), should also be heard, as this organisation consists of Indonesian English teachers and English lecturers in teachers' colleges, who are the 
forefront implementers of any English curriculum innovation. As Emilia (2005) and Korompot (2012) suggested in their studies, since teachers are the most important implementers of any curriculum innovations developed by the government, their voices and their roles should be heard in developing and improving the curriculum. They are not just the objects but the subjects for the improvement of the country's education.

The second reason is the mismatch discussed earlier between the goal of the national examination policy imposed by the government and the objectives of the curricula to enable high school graduates to have communicative competence. Any approach implemented should be streamlined and suited to the objectives of the national examination, until such time as the aims and form of this exam may be considered. The five sub-competences can be reduced into whichever competences are relevant and important, and the Genre-Based Approach can be postponed until the teachers have fully understood and can teach it.

\section{REFERENCES}

Abentao, D. R., Castillo, M. C., Atitiw, J. G., \& Asuncion, M. P. (2018). ESL teaching challenges in the 21 st century in a multicultural context. Baguio City, The Philippines: Saint Louis University.

Agustien, H. I. (2004). Setting up new standards: A preview of Indonesia's new competence-based curriculum. TEFLIN Journal, 15(1).

Agustien, H. I. (2006). Competence-based curriculum and its practical implications. In ITB International Seminar. Bandung, Indonesia.

Alptekin, C. (2002). Towards intercultural communicative competence in ELT. ELT Journal, 56(1), 57-64. https://doi.org/10.1093/elt/56.1.57

Bachman, L. F., \& Palmer, A. S. (1996). Language testing in practice. Oxford, UK: Oxford University Press.

Beacco, J., \& Byram, M. (2007). From linguistic diversity to plurilingual education: Guide for the development of language education policies in Europe. Strasbourg, France: Language Policy Division, Council of Europe. Retrieved from https://www.coe.int/en/web/language-policy/from-linguistic-diversity-toplurilingual-education-guide-for-the-development-of-language-education-policiesin-europe

Beacco, J., Byram, M., Cavalli, M., Coste, D., \& Cuenat, M. E. (2010). Guide for the development and implementation of curricula for plurilingual and intercultural 
education. Strasbourg: Language Policy Division, Directorate of Education and Languages, DGIV, Council of Europe, Strasbourg.

Bellanca, J. (2014). 21st century skills: Rethinking how students learn. In J. Bellanca (Ed.), Deeper learning: Beyond 21 st century skills. Bloomington, Indiana: Solution Tree Press.

Bjork, C. (2005). Indonesian education: Teachers, schools, and central bureaucracy. New York, NY: Taylor \& Francis Group.

Bjork, C. (2013). Teacher training, school norms and teacher effectiveness in Indonesia. In D. Suryadarma \& G. W. Jones (Eds.), Education in Indonesia (pp. 53-67). Singapore: Institute of Southeast Asian Studies.

Board of National Standards of Education. (2006). Panduan penyusunan kurikulum tingkat satuan pendidikan jenjang pendidikan dasar dan menengah (Guide to develop a school-based curriculum for elementary and secondary education). Jakarta, Indonesia: Board of National Standard of Education.

Braine, G. (2010). Nonnative speaker English teachers: Research, pedagogy, and professional growth. New York, NY: Routledge.

Brown, H. D. (2007). Principles of language learning and teaching (5th ed.). White Plains, NY: Pearson Education, Inc.

Brown, H. D., Tarone, E., Swan, M., \& Ellis, Rod, et al. (2007). Forty years of language teaching. Language Teaching, 40(01), 1-15. https://doi.org/10.1017/S0261444806003934

Butler, Y. G. (2011). The Implementation of Communicative and Task-Based Language Teaching in the Asia-Pacific Region. Annual Review of Applied Linguistics, 31, 3657. https://doi.org/10.1017/S0267190511000122

Byram, M. (1997). Teaching and assessing intercultural communicative competence. Bristol, PA: Multilingual Matters.

Byram, M. (2008). From foreign language education to education for intercultural citizenship: Essays and reflections. Tonowanda, NY: Multilingual Matters.

Byram, M. (2012). Intercultural Competence. In The Encyclopedia of Applied Linguistics (pp. 1-4). Oxford, UK: Blackwell Publishing Ltd. https://doi.org/10.1002/9781405198431.wbeal0554

Canale, M., \& Swain, M. (1980). Theoretical bases of communicative approaches to second language teaching and testing. Applied Linguistics, 1(1), 1-47. https://doi.org/10.1093/applin/I.1.1

Celce-Murcia, M., Dörnyei, Z., \& Thurrell, S. (1995). Communicative competence: A pedagogically motivated model with content specifications. Issues in Applied Linguistics, 6(2), 5-35. Retrieved from http://www.escholarship.org/uc/item/2928w4zj

Chang, B. (2011). The roles of English language education in Asian context. Pan-Pacific Association of Applied Lingustics, 15(1), 191-206. 
Chang, M. (2011). Factors affecting the implementation of communicative language teaching in Taiwanese college English classes. English Language Teaching, 4(2), 312. https://doi.org/10.5539/elt.v4n2p3

Choong, K. P. (2006). Multicompetence and second language learning. The Forum, Working Papers in TESOL \& Applied Linguistics, 6(1). Retrieved from https://tesoldev.journals.cdrs.columbia.edu/wp-content/uploads/sites/12/2015/06/3.1-Choong2006.pdf

Cook, V. (1992). Evidence for multicompetence. Language Learning, 42(4), 557-591. https://doi.org/10.1111/j.1467-1770.1992.tb01044.x

Cook, V. (2012). Multi-competence. Retrieved November 15, 2018, from http://www.viviancook.uk/SLA/Multicompetence/index.htm

Cook, V. (2016). Working definition of multi-competence. Retrieved November 15, 2018, from http://www.viviancook.uk/Writings/Papers/MCentry.htm

Coperías-Aguilar, M. J. (2002). Intercultural Communicative Competence: A step beyond communicative competence. Elia, 3(January 2002), 85-102.

Corbett, J. (2003). An intercultural approach to English language teaching. Bristol, UK: Multilingual Matters.

Coste, D., Moore, D., \& Zarate, G. (2009). Plurilingual and pluricultural competence. Strasbourg, France: Language Policy Division, Council of Europe.

Council of Europe. (2001). Common European Framework of Reference for Languages : Learning, Teaching, Assessment. Council of Europe. London, UK: Cambridge University Press. https://doi.org/10.1017/S0267190514000221

Darling-Hammond, L., Hightower, A. M., Husbands, J. L., LaFors, J. R., Young, V. M., \& Christopher, C. (2003). Building instructional quality: "Inside-Out" and "Outside-In" perspectives on San Diego's school reform - A research report. Washington: Center for the Study of Teaching and Policy, University of Washington.

Dede, C. (2009). Comparing frameworks for "21st Century Skills," 1-16. Retrieved from http://sttechnology.pbworks.com/f/Dede_(2010)_Comparing Frameworks for 21st Century Skills.pdf

Didenko, A. V., \& Pichugova, I. L. (2016). Post CLT or Post-Method: major criticisms of the communicative approach and the definition of the current pedagogy. SHS Web of Conferences, 28, 01028. https://doi.org/10.1051/shsconf/20162801028

Djalal, F., Samani, M., Chang, M. C., Stevenson, R., Ragatz, A. B., \& Negara, S. D. (2009). Teacher certification in Indonesia: A strategy for teacher quality improvement. Jakarta, Indonesia: Departemen Pendidikan Nasional Indonesia.

Doyle, H. (2015). Multi-competence, ELF , learning and literacy : A reconsideration. International Journal of Science and Humanity, 5(10). https://doi.org/10.7763/IJSSH.2015.V5.574

Drame, A. (2009). Resistance to communicative language teaching in a foreign language 
context: a Senegalese case study. Liens, 12, 1-17.

Eaton, S. E. (2010). Global trends in language learning in the twenty-first century. Calgary: Onate Press.

Emilia, E. (2005). A critical genre-based approach to teaching academic writing in a tertiary EFL context in Indonesia. The University of Melbourne, Melbourne, Australia.

Hall, J. K., Cheng, A., \& Carlson, M. T. (2006). Reconceptualizing multicompetence as a theory of language knowledge. Applied Linguistics, 27(2), 220-240. https://doi.org/10.1093/applin/aml013

Halliday, M. A. K. (1994). An Introduction to Functional Grammar (2nd ed.). London, UK: Edward Arnold.

Holliday, A. (1994). The house of TESEP and the communicative approach: the special needs of state English language education. ELT Journal, 48(1), 3-11. https://doi.org/10.1093/elt/48.1.3

Huda, N. (1999). Language learning and teaching: Issues and trends. Malang, Indonesia: IKIP Malang.

Hyde, M. (1998). Intercultural competence in English language education. Modern English Teacher, 7(2), 7-11.

Kennedy, E. (2014). A look at the 2013 curriculum. Retrieved June 16, 2016, from https://indonesiaful.com/2014/01/16/2013-curriculum-indonesia/

Korompot, C. A. (2012). Giving teachers their voices: Indonesian EFL teachers' perspectives on professional teaching standards in the context of teacher certification programs in Indonesia. Unpublished Dissertation. The University of New England, Armidale, NSW, Australia.

Kumaravadivelu, B. (2001). Toward a postmethod pedagogy. TESOL Quarterly, 35(4), 537-560.

Kumaravadivelu, B. (2003). Beyond methods: macrostrategies for language teaching. New Haven, CT: Yale University Press.

Kumaravadivelu, B. (2006). TESOL Methods: Changing Tracks, Challenging Trends. TESOL Quarterly, 40(1), 59-81. https://doi.org/10.2307/40264511

Kumaravadivelu, B. (2012). Language teacher education for a global society: A modular model for knowing, analyzing, recognizing, doing, and seeing. New York, USA: Routledge.

Ledward, B. C., \& Hirata, D. (2011). An overview of 21st century skills. Research \& Evaluation - Pacific Policy Research Center., January.

Lie, A. (2007). Education policy and EFL curriculum in Indonesia: Between the commitment to competence and the quest for higher test scores. TEFLIN Journal, $18(1), 1-14$.

Littlewood, W. (2007). Communicative and task-based language teaching in East Asian classrooms. Language Teaching, 40(03), 243-249. 
https://doi.org/10.1017/S0261444807004363

López-Rocha, S. (2016). Intercultural communicative competence: creating awareness and promoting skills in the language classroom. In C. Goria, O. Speicher, \& S. Stollhans (Eds.), Innovative language teaching and learning at university: enhancing participation and collaboration. (pp. 105-111). Dublin: Researchpublishing.net. https://doi.org/10.14705/rpnet.2016.000411

MacKenzie, I. (2012). English as a lingua franca in Europe: bilingualism and multicompetence. International Journal of Multilingualism, 9(1), 83-100. https://doi.org/10.1080/14790718.2011.610506

Madya, S. (2007). Searching for an appropriate EFL curriculum design for the Indonesian pluralistic society. TEFLIN Journal, 18(2), 196-221.

Madya, S. (2008). Curriculum Innovations in Indonesia. In Y. H. Choi \& B. Spolsky (Eds.), ELT curriculum innovation and implementation in Asia (pp. 1-38). Seoul: Asia TEFL.

Marcellino, M. (2008). English language teaching in Indonesia: A continuous challenge in education and cultural diversity. TEFLIN Journal, 19(1), 57-69.

Mattarima, K., \& Hamdan, A. R. (2011). The teaching constraints of English as a foreign language in Indonesia: The context of school-based curriculum. Sosiohumanika, 4(2), 287-300. Retrieved from http://www.sosiohumanikajpssk.com/sh_files/File/Karim.pdf

Ministry of Education and Culture of the Republic of Indonesia. (2014). Permendikbud Republik Indonesia No. 160 tahun 2014 tentang pemberlakuan kurikulum tahun 2006 dan kurikulum 2013 (Ministry of Education and Culture Republic Indonesia Regulation number 160 year 2014 on the implementation of the 2006 and the 2013 curricula. Jakarta, Indonesia: Ministry of Education and Culture, the Republic of Indonesia.

Musa, N. C., Lie, K. Y., \& Azman, H. (2012). Exploring English Language Learning And Teaching In Malaysia. Journal of Language Studies, 12(1). https://doi.org/10.1111/j.1944-9720.2007.tb03201.x

Nunan, D. (1987). Communicative language teaching: Making it work. ELT Journal, 41(2).

Nunan, D. (2003). The impact of English as a global language on educational policies and practices in the Asia-Pacific region. TESOL Quarterly, 37(4), 589-613. https://doi.org/10.2307/3588214

Paige, J. (2009). The 21st century skills movement. Educational Leadership, 67(11).

Pusat Kurikulum Balitbang Depdiknas. (2003). Kurikulum 2004: Standar Kompetensi Mata Pelajaran Bahasa Inggris untuk Sekolah Menengah Atas dan Madrasah Aliyah (2004 curriculum: Competence standards of English language subject for senior high school and madrasah aliyah). Jakarta, Indonesia: Department of National Education, Indonesia.

Pusat Kurikulum Departemen Pendidikan Nasional. (2003). Pengelolaan kurikulum di 
tingkat sekolah (School-based curriculum management). Jakarta, Indonesia:

Departemen Pendidikan Nasional Indonesia.

Rachman, T. (2014, December 8). Seputar keputusan Mendikbud tentang penghentian Kurikulum 2013 (About the Minister of Education \& Culture Decree on the cancelation of 2013 curriculum). Republika Online. Retrieved from http://www.republika.co.id/berita/kemendikbud/beritakemendikbud/14/12/08/ng9bi6-seputar-keputusan-mendikbud-tentang-penghentiankurikulum-2013

Renandya, W. A., \& Widodo, H. P. (Eds.). (2016). English language teaching today: Linking theory and practice. Cham, Switzerland: Springer International Publishing Switzerland. https://doi.org/10.1007/978-3-319-38834-2

Richards, J. C. (2017). Curriculum Development in Language Teaching. Cambridge, United Kingdom: Cambridge University Press.

Richards, J. C. (2006). Communicative language teaching today. New York, NY: Cambridge University Press.

Richards, J. C., \& Rodgers, T. S. (2014). Approaches and methods in language teaching (3rd ed.). Cambridge, United Kingdom: Cambridge University Press.

Sadtono, E. (1997). ELT development in Indonesia: A smorgasboard. In E. Sadtono (Ed.), The development of TEFL in Indonesia (pp. 1-19). Malang, Indonesia: Institut Keguruan dan Ilmu Pendidikan.

Savignon, S. J. (2007). Beyond communicative language teaching: What's ahead? Journal of Pragmatics, 39(1), 207-220. Retrieved from http://www.sciencedirect.com/science/article/pii/S0378216606001809

Scott, V. M. (2015). Multi-competence and language learning. Retrieved November 15, 2018, from https://as.vanderbilt.edu/french-italian/wpcontent/uploads/sites/72/Scott-article-proofs.pdf

Seedhouse, P. (1996). Classroom interaction: possibilities and impossibilities. ELT Journal, 50/1(January), 16-24.

Sercu, L., Bandura, E., Castro, P., Davcheva, L., Laskaridou, C., Lundgren, U., ... Ryan, P. (2005). Foreign language teachers and intercultural competence. Clevedon, UK: Multilingual Matters Ltd.

State Secretariat of the Republic of Indonesia. (2003). Undang-Undang Republik Indonesia Nomor 20 Tahun 2003 Tentang Sistem Pendidikan Nasional (Law number 20 year 2003 on system of national education). Jakarta, Indonesia: State Secretariat of the Republic of Indonesia. Retrieved from http://www.dikti.go.id/files/atur/UU20-2003Sisdiknas.pdf

Sukyadi, D. (2015). The teaching of English at secondary schools in Indonesia. In B. Spolsky \& K. Sung (Eds.), Secondary school English education in Asia: From policy to practice. New York, NY: Routledge.

Sun, Y. (2016). 9 strategies for 21st-century ELT professionals. Retrieved November 15, 2018, from http://blog.tesol.org/9-strategies-for-21st-century-elt-professionals/\# 
Swan, M. (1985). A critical look at the Communicative Approach (1). ELT Journal, $39(1)$.

The British Council. (1975). English language teaching profile: Indonesia. London, UK: The British Council.

Thompson, G. (1996). Some misconceptions about communicative language teaching. ELT Journal, 50/l(January), 9-15. https://doi.org/10.1093/elt/50.1.9

Trilling, B., \& Fadel, C. (2009). 21 st century skills: Learning for life in our times. Partnership for 21St Century Skills. San Francisco, CA: Jossey-Bass.

Vongxay, H. (2013). The implementation of Communicative Language Teaching (CLT) in an English Department in a Lao higher educational institution: A case study. Master Thesis: Unitec Institution of Technology, New Zealand.

Widdowson, H. G. (2007). Un-applied linguistics and communicative language teaching. International Journal of Applied Linguistics, 17(2), 214-220. https://doi.org/10.1111/j.1473-4192.2007.00155.x

Widdowson, H. G. (2009). The linguistic perspective. In K. Knapp, B. Seidlhofer, \& H. Widdowson (Eds.), Handbook of foreign language communication and learning, volume 6 (pp. 193-218). Berlin: Walter De Gruyter \& Company.

Widodo, H. P. (2016). Language policy in practice: Reframing the English language curriculum in the Indonesian secondary education sector. In R. Kirkpatrick (Ed.), English language education policy in Asia (Vol. 11, pp. 127-151). Cham: Springer International Publishing Switzerland. https://doi.org/10.1007/978-3-319-22464-0_6

Yue, L., Chu, Y., \& Li, H. (2006). The influence of variable semen white blood cells volumetric count on sperm acrosin activity. In J. Zajda (Ed.), Chinese Journal of Andrology (Vol. 20, pp. 133-150). The Netherlands: Springer. https://doi.org/10.1007/978-1-4020-3358-2

Yulia, Y. (2014). An evaluation of English language teaching programs in Indonesian junior high schools in the Yogyakarta Province. Royal Melbourne Institute of Technology, Melbourne, Australia. Retrieved from https://researchbank.rmit.edu.au/eserv/rmit:160956/Yulia.pdf

Yulia, Y. (2015). Teachers' views on Communicative Language Teaching: A case study of twelve Indonesian junior high schools. In TEFLIN (Ed.), TEFLIN International Conference, Bali, Indonesia (pp. 1-6). Denpasar, Bali, Indonesia: TEFLIN. 